Polymer Journal, Vol. 9, No. 6, 561-568 (1977)

\title{
Studies of Nitrogen-Phosphorus Compounds. XXIX.* Synthesis and Thermal Stability of Phosphorus Diamide Nitride Resins
}

\author{
Etsuro Kobayashi and Tadao Kanayama \\ National Chemical Laboratory for Industry, \\ Hon-machi, Shibuya-ku, Tokyo 151, Japan.
}

(Received March 12, 1977)

\begin{abstract}
The synthesis of resins by the reaction of trimeric or tetrameric phosphorus diamide nitride $\left(\mathrm{N}_{n} \mathrm{P}_{n}\left(\mathrm{NH}_{2}\right)_{2 n}, n=3,4\right)$ with formalin $\left(\mathrm{CH}_{2} \mathrm{O}\right)$, and the possibility of the formation of co-condensation resins through the addition of urea $\left(\mathrm{CO}\left(\mathrm{NH}_{2}\right)_{2}\right)$ or melamine $\left(\mathrm{C}_{3} \mathrm{H}_{6} \mathrm{~N}_{6}\right)$ in the above reaction system have been investigated. Moreover, the thermal stability of resins has been studied by the DTA and TGA methods. In the $\mathrm{N}_{n} \mathrm{P}_{n}\left(\mathrm{NH}_{2}\right)_{2 n}-\mathrm{CH}_{2} \mathrm{O}$ system $(n=3,4)$, the rate of gelation increased with a decrease in $\mathrm{pH}$, and remarkably accelerated with an increase in temperature. A mixture of these components in a suitable molar ratio was neutral and gelatinized gradually at $50^{\circ} \mathrm{C}$ within a period of $1-4 \mathrm{~h}$. The gelatinous product was converted into a transparent resin at $80^{\circ} \mathrm{C}$. The proper quantities of formalin were $7.5-9$ and $16-20 \mathrm{~mol}$ to $1 \mathrm{~mol}$ of $\mathrm{N}_{3} \mathrm{P}_{3}\left(\mathrm{NH}_{2}\right)_{6}$ and $\mathrm{N}_{4} \mathrm{P}_{4}\left(\mathrm{NH}_{2}\right)_{8}$, respectively. The rate of gelation for the tetramer was distinctly greater than that of the trimer variety. In the $\mathrm{N}_{3} \mathrm{P}_{3}\left(\mathrm{NH}_{2}\right)_{6}-\mathrm{CO}\left(\mathrm{NH}_{2}\right)_{2}-\mathrm{CH}_{2} \mathrm{O}$ and $\mathrm{N}_{3} \mathrm{P}_{3}\left(\mathrm{NH}_{2}\right)_{6}-\mathrm{C}_{3} \mathrm{H}_{6} \mathrm{~N}_{6}-\mathrm{CH}_{2} \mathrm{O}$ systems, the transparent resins were obtained in molar ratios of $1: 2.5-10$ and $1: 1-20$ of urea and melamine to the trimer variety, respectively. The resin of $\mathrm{N}_{n} \mathrm{P}_{n}\left(\mathrm{NH}_{2}\right)_{2 n}-\mathrm{CH}_{2} \mathrm{O}$ system was found to be $\mathrm{P} 23-26 \%$, and $\mathrm{N} 29-33 \%$. The resin formed by the addition of urea or melamine naturally decreased the $\mathrm{P}$ content, while the $\mathrm{N}$ content did not vary appreciably. The thermal decomposition of resins reacted with $\mathrm{N}_{n} \mathrm{P}_{n}\left(\mathrm{NH}_{2}\right)_{2 n}$ shifted more to the lower temperature side than did the urea-formalin and melamine-formalin resins. However, their carbonized residues formed remarkably, checked the spread of fire, and were incinerated at about $800^{\circ} \mathrm{C}$.

KEY WORDS Phosphorus Diamide Nitrides (Aminophosphazenes) /

Formalin / Urea / Melamine / Thermal Stability /
\end{abstract}

The amidated derivatives of the trimeric and tetrameric phosphorus dichloride nitrides have drawn interest as fireproof materials, ${ }^{1,2}$ and fertilizer. ${ }^{3,4}$ The present authors previously investigated the synthesis of $\mathrm{N}_{3} \mathrm{P}_{3}\left(\mathrm{NH}_{2}\right)_{6}{ }^{5}$ and $\mathrm{N}_{4} \mathrm{P}_{4}\left(\mathrm{NH}_{2}\right)_{8}{ }^{6}$ and their hydrolysis behavior and thermal decomposition. ${ }^{6-8}$ Audrieth and Sowerby had already reported the formation of resins by reacting $\mathrm{N}_{n} \mathrm{P}_{n}\left(\mathrm{NH}_{2}\right)_{2 n} \quad(n=3,4)$ with formalin $\left(\mathrm{CH}_{2} \mathrm{O}\right),{ }^{9}$ however, the condition for synthesis of the resin and its character were not described at all in their report. Recently, it has become a matter of great importance that the environ-

* Part XXVIII of this series: E. Kobayashi and T. Kanayama, Bull. Chem. Soc. Jpn., 47, 307 (1977). ment be free from fire accidents, then the development of incombustible materials may be considered as one significant theme. In this work, the suitable conditions for synthesis of the resin from $\mathrm{N}_{n} \mathrm{P}_{n}\left(\mathrm{NH}_{2}\right)_{2 n}$ and formalin are presented, and an attempt is made to prepare co-condensation resins using $\mathrm{N}_{n} \mathrm{P}_{n}\left(\mathrm{NH}_{2}\right)_{2 n}$, urea $\left(\mathrm{CO}\left(\mathrm{NH}_{2}\right)_{2}\right)$ or melamine $\left(\mathrm{C}_{3} \mathrm{H}_{6} \mathrm{~N}_{6}\right)$, and formalin. Moreover, the stability of resins formed is studied by means of thermal analysis.

\section{EXPERIMENTAL}

Preparation of $\mathrm{N}_{n} \mathrm{P}_{n}\left(\mathrm{NH}_{2}\right)_{2 n}(n=3,4)$

$\mathrm{N}_{3} \mathrm{P}_{3}\left(\mathrm{NH}_{2}\right)_{6} \cdot \mathrm{H}_{2} \mathrm{O}$ and $\mathrm{N}_{4} \mathrm{P}_{4}\left(\mathrm{NH}_{2}\right)_{8} \cdot \mathrm{H}_{2} \mathrm{O}$ were obtained by previously reported methods. ${ }^{5,6}$ 


\section{E. Kobayashi and T. Kanayama}

Synthesis of Resins

A 0.25 -g portion of $\mathrm{N}_{n} \mathrm{P}_{n}\left(\mathrm{NH}_{2}\right)_{2 n}$ was placed in a $10 \mathrm{~m} l$ test tube (diameter $18 \mathrm{~mm}$, height 43 $\mathrm{mm}$ ), and dissolved in water and $37 . \%$ formalin. For adjustment of the $\mathrm{pH}$, a small amount of hydrochloric acid or an aqueous solution of sodium hydroxide was occasionally added to the mixed solution. To the test tube was fixed a glass tube (diameter $5 \mathrm{~mm}$, length $25 \mathrm{~cm}$ ), for reflux, and the tube was then immersed in a water bath maintained at the proper temperature. The viscosity of this solution increased with the degree of condensation. The resulting gelatinous product was removed to a crystallizing dish, and dried by an infrared lamp at $50-60^{\circ} \mathrm{C}$ for $8 \mathrm{~h}$. The product was finally converted into a transparent resin by dehydration at $105^{\circ} \mathrm{C}$.

\section{Analysis of $P$ and $N$}

Exactly $0.5 \mathrm{~g}$ of the resin powdered was weighed out and then heated on the addition of some water with $3 \mathrm{ml}$ of the concentrated sulfuric acid in a Kjeldahl flask, until the resin had decomposed completely. The volume of sample was adjusted to $250 \mathrm{~m} l$ with distilled water. The phosphorus content was determined gravimetrically as magnesium pyrophosphate. The total nitrogen content was determined by Kjeldahl's method.

\section{$D T A$ and $T G A$}

The differential thermal analysis (DTA) and thermogravimetric analysis (TGA) were performed simultaneously at a heating rate of $10^{\circ} \mathrm{C} / \mathrm{min}$ with a Rigaku Denki micro-type thermal analyzer.

\section{IR Spectra}

The infrared absorption spectra were measured with a Hitachi model EPI-2S infrared spectro. photometer applying the method of $\mathrm{KBr}$ disk.

\section{RESULTS AND DISCUSSION}

Synthesis of Resin using $\mathrm{N}_{n} \mathrm{P}_{n}\left(\mathrm{NH}_{2}\right)_{2 n}$ and $\mathrm{CH}_{2} \mathrm{O}$

The synthesizing conditions of a resin and its analytical results are summarized in Table I.

The gelation time, the period in which the fluidity of the reaction mixture is lost, varied

Table I. Formation of resin by addition condensation between phosphorus diamides nitride and formalin and its analysis

\begin{tabular}{|c|c|c|c|c|c|c|c|c|c|c|c|}
\hline \multirow[b]{2}{*}{ No. } & \multicolumn{8}{|c|}{ Reaction condition } & \multirow[b]{2}{*}{$\begin{array}{l}\text { Resin } \\
\text { yield, } \\
\text { g }\end{array}$} & \multicolumn{2}{|c|}{ Analysis } \\
\hline & $\begin{array}{r}\mathrm{N}_{3} \mathrm{P}_{3}(\mathrm{NH} \\
\mathrm{N}_{4} \mathrm{P}_{4}(\mathrm{NH} \\
\mathrm{g}\end{array}$ & 2) $6(\Delta)$ & $\begin{array}{l}37 \% \\
\mathrm{CH}_{2} \mathrm{O} \\
\mathrm{g}\end{array}$ & $\begin{array}{c}\mathrm{H}_{2} \mathrm{O} \\
\mathrm{ml}\end{array}$ & $\begin{aligned} & \mathrm{CH}_{2} \mathrm{O} / \\
& \mathrm{N}_{3} \mathrm{P}_{3}\left(\mathrm{NH}_{2}\right)_{6}, \\
& \text { or } \mathrm{N}_{4} \mathrm{P}_{4}\left(\mathrm{NH}_{2}\right)_{8}, \\
& \text { molar ratio }\end{aligned}$ & $\mathrm{pH}$ & $\underset{{ }^{\circ} \mathrm{C}}{\text { Temp, }}$ & $\begin{array}{c}\text { Gelation } \\
\text { time } \\
\text { hr }\end{array}$ & & $\begin{array}{l}\mathrm{P}, \\
\%\end{array}$ & $\begin{array}{l}\mathrm{N}, \\
\%\end{array}$ \\
\hline 1 & 0.50 & $\triangle$ & 1.35 & 2.50 & 9 & 6.4 & 50 & 1.2 & 1.08 & 17.6 & 21.8 \\
\hline 2 & 0.50 & $\triangle$ & 1.35 & 2.50 & 9 & 8.2 & 50 & 4.0 & 0.79 & 25.5 & 32.4 \\
\hline 3 & 0.50 & $\triangle$ & 1.35 & 2.50 & 9 & 11.8 & 50 & 21.0 & 0.57 & 25.0 & 32.3 \\
\hline 4 & 0.33 & $\square$ & 1.30 & 1.63 & 16 & 6.2 & 50 & 0.5 & 0.55 & 23.4 & 28.9 \\
\hline 5 & 0.33 & $\square$ & 1.30 & 1.63 & 16 & 7.8 & 50 & 1.2 & 0.53 & 23.4 & 30.1 \\
\hline 6 & 0.33 & $\square$ & 1.30 & 1.63 & 16 & 11.6 & 50 & 15.0 & 0.59 & 21.6 & 27.6 \\
\hline 7 & 0.25 & $\triangle$ & 0.90 & 1.25 & 12 & $7.6-6.2$ & $20 \pm 1$ & 4 (day) & 0.47 & 24.4 & 30.9 \\
\hline 8 & 0.65 & $\square$ & 2.60 & 5.00 & 16 & $7.4-6.0$ & $20 \pm 1$ & 2.5 (day) & 1.02 & 23.6 & 26.3 \\
\hline 9 & 0.25 & $\triangle$ & 0.90 & 1.25 & 12 & 7.6 & 50 & 3.5 & 0.44 & 23.3 & 29.6 \\
\hline 10 & 0.25 & $\triangle$ & 0.90 & 1.25 & 12 & 7.0 & 70 & 0.6 & 0.45 & 23.7 & 25.1 \\
\hline 11 & 0.25 & $\triangle$ & 0.45 & 1.25 & 6 & 8.4 & 50 & 1.5 & 0.36 & 14.9 & 18.4 \\
\hline 12 & 0.25 & $\triangle$ & 0.56 & 1.25 & 7.5 & 8.3 & 50 & 2.5 & 0.41 & 24.0 & 29.7 \\
\hline 13 & 0.25 & $\triangle$ & 0.68 & 1.25 & 9 & 8.2 & 50 & 3.0 & 0.42 & 24.1 & 30.4 \\
\hline 14 & 0.33 & $\square$ & 0.65 & 1.63 & 8 & 8.4 & 50 & 0.3 & 0.46 & 28.5 & 36.1 \\
\hline 15 & 0.33 & $\square$ & 1.63 & 1.63 & 20 & 7.2 & 50 & 2.0 & 0.59 & 21.6 & 27.8 \\
\hline 16 & 0.33 & $\square$ & 0.98 & 1.63 & 12 & 8.2 & 50 & 0.7 & 0.50 & 25.3 & 32.5 \\
\hline 17 & 0.25 & $\triangle$ & 0.68 & 0.00 & 9 & 8.2 & 50 & 0.3 & 0.41 & 26.2 & 34.6 \\
\hline 18 & 0.25 & $\triangle$ & 0.68 & 1.25 & 9 & 8.1 & 50 & 3.0 & 0.40 & 25.2 & 31.7 \\
\hline 19 & 0.25 & $\triangle$ & 0.68 & 2.50 & 9 & 8.1 & 50 & 3.3 & 0.39 & 26.5 & 33.6 \\
\hline
\end{tabular}


markedly with respect to the $\mathrm{pH}$ value of the reaction mixture. In an acid solution, the reaction between the trimeric or tetrameric phosphorus diamide nitride and formalin took place immediately, though the resulting gelatinous product redissolved at elevated temperatures. It may be considered that the dissolution of gelatinous product occurs by hydrolysis of the $\mathrm{N}_{n} \mathrm{P}_{n}\left(\mathrm{NH}_{2}\right)_{2 n}$ in the acid solution. In No. 1 and 4 , hydrochloric acid was added to the reaction system; the gelation proceeded for fairly short time, and then a brittle resin was obtained. Numbers 2 and 5 are mixtures in the suitable molar ratio of $\mathrm{N}_{n} \mathrm{P}_{n}\left(\mathrm{NH}_{2}\right)_{2 n}$ having a $\mathrm{pH}$ of 8.9 with the formalin at a $\mathrm{pH}$ of 3.3. These reaction mixtures were roughly neutral and gelatinized at $50^{\circ} \mathrm{C}$ within $1-4 \mathrm{~h}$. The gelatinous products were converted into transparent resins at elevated temperatures. In No. 3 and 6 , the reaction mixture was alkalized with an aqueous solution of sodium hydroxide.

It can be expected that the reaction of $\mathrm{N}_{n} \mathrm{P}_{n}\left(\mathrm{NH}_{2}\right)_{2 n}$ with $\mathrm{CH}_{2} \mathrm{O}$ is roughly the same as that of $\mathrm{CO}\left(\mathrm{NH}_{2}\right)_{2}$ or $\mathrm{C}_{3} \mathrm{H}_{6} \mathrm{~N}_{6}$ with $\mathrm{CH}_{2} \mathrm{O}$. At the beginning of the reaction, formalin reacts to an amide radical in $\mathrm{N}_{n} \mathrm{P}_{n}\left(\mathrm{NH}_{2}\right)_{2 n}$ and forms the methylol and methylene radicals. Further, the condensation of methylol with amide easily occurs in the presence of an acidic catalyst, while, the addition reaction between methylol radicals takes precedence with a basic catalyst. Therefore, the difference of the gelation time naturally appeared in the reactions of acid and alkali solutions.

Gelation on using the tetramer variety was undoubtedly performed for shorter time than that of trimer variety. In No. 7 and 10, the effect of temperature on the gelation time was examined. The gelation time using the trimer and the tetramer varieties required 4 and 2.5 days at room temperature $\left(20^{\circ} \mathrm{C}\right)$, respectively. However, the rate of gelation was remarkably accelerated with an increase in temperature. In No. 5, 9, and 11-16, the quantities of formalin were examined. The required values of formalin are 6 and $8 \mathrm{~mol}$ to $1 \mathrm{~mol}$ of $\mathrm{N}_{3} \mathrm{P}_{3}\left(\mathrm{NH}_{2}\right)_{6}$ and $\mathrm{N}_{4} \mathrm{P}_{4}\left(\mathrm{NH}_{2}\right)_{8}$, respectively. The gelation for theoretical molar ratios (No. 11, 14) took place in short periods such as $1.5 \mathrm{~h}$ for the trimer variety and $0.3 \mathrm{~h}$ for the tetramer variety. The gelation

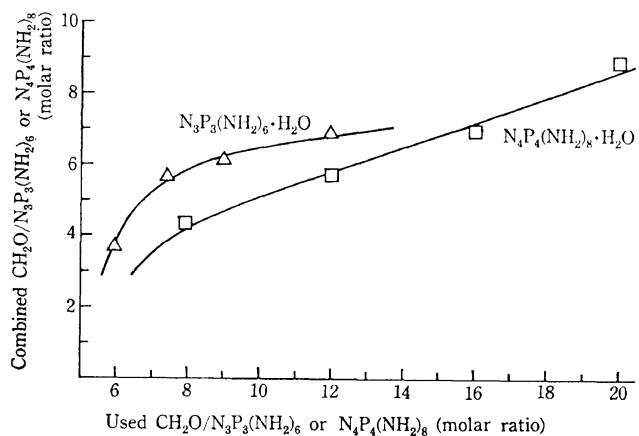

Figure 1. Relation between combined formalin and used formalin.

time was prolonged with an increase in the molar ratio of $\mathrm{CH}_{2} \mathrm{O}$ to $\mathrm{N}_{n} \mathrm{P}_{n}\left(\mathrm{NH}_{2}\right)_{2 n}$. The relation between the amount of combined formalin and that of used formalin is shown in Figure 1.

From these results, it was found that the formalin actually used 7.5-9 mol and about 16$20 \mathrm{~mol}$ to $1 \mathrm{~mol}$ of $\mathrm{N}_{3} \mathrm{P}_{3}\left(\mathrm{NH}_{2}\right)_{6}$ and $\mathrm{N}_{4} \mathrm{P}_{4}\left(\mathrm{NH}_{2}\right)_{8}$, respectively. When an excess of formalin was used for the reaction, the combined formalin for the trimer and tetramer varieties was more than 6 and $8 \mathrm{~mol}$ of the theoretical values as shown in Figure 1. The slight difference between the value of combined formalin and the theoretical value may be caused by the free formalin included in the resin. In No. 17-19, the effect of water was examined. If no water was added to the reaction system, the gelation quickly progressed, and an opaque resin was formed by a heterogeneous reaction. However, the gelation time was prolonged by the addition of this water.

Reactions between Phosphorus Diamide Nitride, Urea (or Melamine) and Formalin

When urea and melamine resins are used as structural materials, incombustibility cannot be expected. For incombustibility of these resins, a fireproofing agent such as ammonium phosphate was mixed as an additive to the resin. In this case, there is danger of harming the appearance of the resin by salting out the additive. As mentioned after, the resin obtained by the reaction between phosphorus diamide nitride and formalin contains about $25 \% \mathrm{P}$, and shows remarkable incombustibility. If a homogeneous copolycondensation product can be formed by reaction of phosphorus diamide nitride, a certain 
Table II. Formation of resin by reaction of $\mathrm{N}_{3} \mathrm{P}_{3}\left(\mathrm{NH}_{2}\right)_{6}, \mathrm{CO}\left(\mathrm{NH}_{2}\right)_{2}\left(\right.$ or $\left.\mathrm{C}_{3} \mathrm{H}_{6} \mathrm{~N}_{6}\right)$ and $\mathrm{CH}_{2} \mathrm{O}$, and its analysis

Reaction condition

Analysis

\begin{tabular}{|c|c|c|c|c|c|c|c|c|c|c|c|}
\hline No. & $\underset{\mathrm{g}}{\mathrm{N}_{3} \mathrm{P}_{3}\left(\mathrm{NH}_{2}\right)_{6}(\mathrm{P})}$ & $\begin{array}{c}\mathrm{CO}\left(\mathrm{NH}_{2}\right)_{2}(\mathrm{U}) \\
\text { or } \mathrm{C}_{3} \mathrm{H}_{6} \mathrm{~N}_{6}(\mathrm{M}) \\
\mathrm{g}\end{array}$ & $\begin{array}{c}\mathrm{U} \text { or } \mathrm{M} / \\
\mathrm{P}, \\
\text { molar ratio }\end{array}$ & $\begin{array}{c}37 \% \\
\mathrm{CH}_{2} \mathrm{O} \\
\mathrm{g}\end{array}$ & $\begin{array}{c}\mathrm{CH}_{2} \mathrm{O} / \\
\mathrm{P}+\mathrm{U} \text { or } \\
\mathrm{P}+\mathrm{M}, \\
\text { molar ratio }\end{array}$ & $\mathrm{pH}$ & $\underset{{ }^{\circ}}{\text { Temp }}$ & $\begin{array}{l}\text { Gelation } \\
\text { time, } \\
\text { hr }\end{array}$ & $\begin{array}{l}\text { Resin } \\
\text { yield, } \\
\text { g }\end{array}$ & $\begin{array}{l}\mathrm{P}, \\
8\end{array}$ & $\begin{array}{l}\mathrm{N}, \\
i ;\end{array}$ \\
\hline 20 & 0.00 & U6.00 & 0.0 & 20.3 & 2.5 & 5.6 & 80 & 5.0 & 9.40 & 0.0 & 27.5 \\
\hline 21 & 0.25 & U0.05 & 0.83 & 0.90 & 6.1 & 5.4 & 50 & 0.18 & 0.63 & 19.4 & 29.1 \\
\hline 22 & 0.25 & U0.15 & 2.5 & 1.19 & 4.2 & 5.4 & 50 & 0.4 & 0.75 & 12.3 & 24.6 \\
\hline 23 & 0.25 & U0.30 & 5.0 & 1.71 & 3.5 & 5.6 & 50 & 0.9 & 1.01 & 8.9 & 24.9 \\
\hline 24 & 0.25 & U0.60 & 10 & 2.71 & 3.0 & 5.4 & 50 & 1.3 & 1.50 & 5.9 & \\
\hline 25 & 0.25 & $\mathrm{U} 1.20$ & 20 & 3.92 & 2.4 & 5.6 & 50 & 1.5 & 2.30 & 3.9 & 26.9 \\
\hline 26 & 0.00 & M6.30 & 0.0 & 24.4 & 6.0 & 5.6 & 65 & 7.0 & 13.1 & 0.0 & 28.7 \\
\hline 27 & 0.25 & M0.042 & 0.33 & 0.89 & 8.2 & 5.2 & 50 & 0.13 & 0.56 & 17.4 & 28.4 \\
\hline 28 & 0.25 & M0.13 & 1.0 & 1.22 & 7.6 & 5.6 & 50 & 0.17 & 0.58 & 13.9 & 30.5 \\
\hline 29 & 0.25 & M0.32 & 2.5 & 1.94 & 6.8 & 5.2 & 50 & 0.3 & 1.00 & 9.2 & 31.7 \\
\hline 30 & 0.25 & M0.63 & 5.0 & 3.16 & 6.5 & 5.3 & 50 & 0.4 & 1.65 & 5.7 & 31.9 \\
\hline 31 & 0.25 & M1.26 & 10 & 5.59 & 6.3 & 5.5 & 50 & 0.7 & 2.85 & 3.2 & 32.3 \\
\hline 32 & 0.25 & M2.52 & 20 & 10.5 & 6.1 & 5.6 & 50 & 1.0 & 5.67 & 1.7 & 30.8 \\
\hline 33 & 0.25 & M3.15 & 25 & 12.9 & 6.1 & 5.6 & 50 & 5.0 & 6.92 & 1.1 & 30.1 \\
\hline
\end{tabular}

amide compound and formalin, the resulting product is a new resin, and may be expected to be fire resistance. In this work, urea and melamine, known to be the raw materials of resins, were chosen. And the copolycondensations between $\mathrm{N}_{3} \mathrm{P}_{3}\left(\mathrm{NH}_{2}\right)_{6}, \mathrm{CO}\left(\mathrm{NH}_{2}\right)_{2}\left(\right.$ or $\left.\mathrm{C}_{3} \mathrm{H}_{6} \mathrm{~N}_{6}\right)$ and $\mathrm{CH}_{2} \mathrm{O}$ were studied. The results are summarized in Table II.

$\mathrm{N}_{3} \mathrm{P}_{3}\left(\mathrm{NH}_{2}\right)_{6}-\mathrm{CO}\left(\mathrm{NH}_{2}\right)_{2}-\mathrm{CH}_{2} \mathrm{O}$ System

In No. 20 (urea resin) and $21-25$, the $\mathrm{pH}$ values of the reaction mixture were roughly the same (5.4-5.6). The rate of gelation was remarkably accelerated by the addition of the trimer variety. At elevated temperatures such as $70-80^{\circ} \mathrm{C}$, the gelation took place for $2-5$ min, thus the reaction between $\mathrm{N}_{3} \mathrm{P}_{3}\left(\mathrm{NH}_{2}\right)_{6}$, $\mathrm{CO}\left(\mathrm{NH}_{2}\right)_{2}$, and $\mathrm{CH}_{2} \mathrm{O}$ was carried out at $50^{\circ} \mathrm{C}$ chosen as the suitable temperature. The rate of gelation in the three-component system was greater than that of the $\mathrm{N}_{3} \mathrm{P}_{3}\left(\mathrm{NH}_{2}\right)_{6}-\mathrm{CH}_{2} \mathrm{O}$ system at the same temperature. This may be caused by a decrease in the $\mathrm{pH}$ value of the three-component system. The gelation time was slightly prolonged by increasing the molar ratio of $\mathrm{CO}\left(\mathrm{NH}_{2}\right)_{2}$ to $\mathrm{N}_{3} \mathrm{P}_{3}\left(\mathrm{NH}_{2}\right)_{6}$. A transparent gelatinous product was formed within a molarratio range from 2.5 to 10 . However, a white precipitate formed along with the gel in these molar ratios, which are either less than 1 or more than 10, and then an unhomogeneous reaction undoubtedly took place. The gelatinous product obtained with this suitable molar ratio was finally converted into a hard bright resin by dehydration at an elevated temperature.

$\mathrm{N}_{3} \mathrm{P}_{3}\left(\mathrm{NH}_{2}\right)_{6}-\mathrm{C}_{3} \mathrm{H}_{6} \mathrm{~N}_{6}-\mathrm{CH}_{2} \mathrm{O}$ System

In No. 26 (melamine resin) and 27-33, the gelation time for the $\mathrm{N}_{3} \mathrm{P}_{3}\left(\mathrm{NH}_{2}\right)_{6}-\mathrm{C}_{3} \mathrm{H}_{6} \mathrm{~N}_{6}-\mathrm{CH}_{2} \mathrm{O}$ system was markedly shorter than that of the $\mathrm{C}_{3} \mathrm{H}_{6} \mathrm{~N}_{6}-\mathrm{CH}_{2} \mathrm{O}$ system. The increase in the molar ratio of $\mathrm{C}_{3} \mathrm{H}_{6} \mathrm{~N}_{6}$ to $\mathrm{N}_{3} \mathrm{P}_{3}\left(\mathrm{NH}_{2}\right)_{6}$ distinctly prolonged the gelation time. The transparent gel was formed over a molar ratio range from 1 to 20. However, for the molar ratios, being either less than 1 or more than 20, a heterogeneous reaction accompanied with white precipitate took place. Thus the final transparent resin obtained, could be formed over a wider range of the molar ratio of $\mathrm{C}_{3} \mathrm{H}_{6} \mathrm{~N}_{6}$ to $\mathrm{N}_{3} \mathrm{P}_{3}\left(\mathrm{NH}_{2}\right)_{6}$ than the molar ratio of $\mathrm{CO}\left(\mathrm{NH}_{2}\right)_{2}$ to $\mathrm{N}_{3} \mathrm{P}_{3}\left(\mathrm{NH}_{2}\right)_{6}$ in the case where urea was added. Perhaps, the reason for this may be as follows: the cyclic molecular structure of the trimer of phosphorus diamide nitride bears somewhat more resemblance to that of melamine than does urea; $\mathrm{N}_{3} \mathrm{P}_{3}\left(\mathrm{NH}_{2}\right)_{6}$ and $\mathrm{C}_{3} \mathrm{H}_{6} \mathrm{~N}_{6}$ has the character of a mixture. 


\section{Contents of Phosphorus and Nitrogen}

The excellent incombustibility of phosphorus is common knowledge; also nitrogen shows a slight fireproof effect. This incombustibility may be expected due to the interaction between phosphorus and nitrogen, thus a certain phosphorusnitrogen compound is useful as a fireproof agent for cellulose. ${ }^{10}$ In the resins synthesized under the suitable conditions shown in Table 1 , analysis showed $25-26 \% \mathrm{P}$ and $32-36 \% \mathrm{~N}$ for the resin of the $\mathrm{N}_{3} \mathrm{P}_{3}\left(\mathrm{NH}_{2}\right)_{6}-\mathrm{CH}_{2} \mathrm{O}$ system and $23-24 \% \mathrm{P}$ and $29-30 \% \mathrm{~N}$ for the resin of the $\mathrm{N}_{4} \mathrm{P}_{4}\left(\mathrm{NH}_{2}\right)_{6}$ $\mathrm{CH}_{2} \mathrm{O}$ system. As shown in Table II, the resins formed by the addition of urea or melamine decreased the phosphorus content. While the nitrogen content varied within the range of $24-27$ and $28-33 \%$ by the addition of urea and melamine, respectively.

\section{Formation of Co-condensation Resin}

It has been confirmed whether or not cocondensation took place in the synthesis of $\mathrm{P}$ $\mathrm{U}-\mathrm{F}$ and $\mathrm{P}-\mathrm{M}-\mathrm{F}$ resins. Products precipitated by adding methyl alcohol to the reaction mixture before and after gelation were prepared, and their phosphorus and nitrogen contents were determined. The preparative conditions of products and analytical results are summarized in Table III.

From these results, the product components before gelation agreed roughly with those of the product after gelation and the completed resin. Therefore, it may be expected that the co-condensations actually took place in the formation of $\mathrm{P}-\mathrm{U}-\mathrm{F}$ and $\mathrm{P}-\mathrm{M}-\mathrm{F}$ resins.
As mentioned previously, the gelations of the urea and melamine resins were perfected for 5.0 and $7.0 \mathrm{~h}$ at 80 and $65^{\circ} \mathrm{C}$, respectively. If the gelations in the $U-F$ and $M-F$ systems are carried out at $50^{\circ} \mathrm{C}$, they will require long periods such as about $45-50$ and $22-25 \mathrm{~h}$. But, the reaction rate was remarkably accelerated by the addition of $\mathrm{N}_{n} \mathrm{P}_{n}\left(\mathrm{NH}_{2}\right)_{2 n}(n=3,4)$, and then the gelation time shortened as in the formation of the $\mathrm{P}-\mathrm{U}$ resin shown in Table $\mathrm{I}$. The above circumstance may prove considerably that the co-condensations take place in the $\mathrm{P}-\mathrm{U}-\mathrm{F}$ and $\mathrm{P}-\mathrm{M}-\mathrm{F}$ systems.

\section{Infrared Absorption Spectra}

The infrared absorption spectra of $\mathrm{N}_{3} \mathrm{P}_{3}\left(\mathrm{NH}_{2}\right)_{6}$. $\mathrm{H}_{2} \mathrm{O}$ and several resins are shown in Fig. 2. In these spectra, the absorption bands may be assigned as follows: there were $\mathrm{N}-\mathrm{H}$ stretching vibrations at $3375-3257 \mathrm{~cm}^{-1}$. The absorption band at $1643 \mathrm{~cm}^{-1}$ in the resin of the $\mathrm{N}_{3} \mathrm{P}_{3}\left(\mathrm{NH}_{2}\right)_{6}-$ $\mathrm{CO}\left(\mathrm{NH}_{2}\right)_{2}-\mathrm{CH}_{2} \mathrm{O}$ system was the $\mathrm{C}=\mathrm{O}$ stretching vibration. In the resin of the $\mathrm{N}_{3} \mathrm{P}_{3}\left(\mathrm{NH}_{2}\right)_{6}-$ $\mathrm{C}_{3} \mathrm{H}_{6} \mathrm{~N}_{6}-\mathrm{CH}_{2} \mathrm{O}$ system, an absorption band based on the $\mathrm{C}=\mathrm{N}$ stretching vibration should appear near $1650 \mathrm{~cm}^{-1}$. However, the absorption band was not clear owing to the overlap of the $\mathbf{H}$ $\mathrm{N}-\mathrm{H}$ bending mode at $1560-1500 \mathrm{~cm}^{-1}$. There were $\mathrm{H}-\mathrm{C}-\mathrm{H}$ bending mode at $1390-1370 \mathrm{~cm}^{-1}$ and $\mathrm{P}-\mathrm{N}$ stretching vibration in the trimeric phosphorus nitride compounds at 1185-1175 $\mathrm{cm}^{-1}$. The absorption bands related to the $\mathrm{NH}_{2}$ radical and the $\mathrm{P}-\mathrm{N}$ bond appeared near 910 and $750 \mathrm{~cm}^{-1}$, respectively. The characteristic peak for the melamine derivatives appeared at

Table III. Formation of product before and after gelation and its analysis

\begin{tabular}{|c|c|c|c|c|c|c|c|c|c|c|c|}
\hline \multirow[b]{2}{*}{ No. ${ }^{a}$} & \multicolumn{9}{|c|}{ Preparation condition } & \multicolumn{2}{|c|}{ Analysis } \\
\hline & $\begin{array}{c}\mathrm{N}_{3} \mathrm{P}_{3}\left(\mathrm{NH}_{2}\right)_{6}(\mathrm{P}) \\
\mathrm{g}\end{array}$ & $\begin{array}{c}\mathrm{CO}\left(\mathrm{NH}_{2}\right)_{2}(\mathrm{U}) \\
\text { or } \mathrm{C}_{3} \mathrm{H}_{6} \mathrm{~N}_{6}(\mathrm{M}) \text {, } \\
\mathrm{g}\end{array}$ & $\begin{array}{c}\mathrm{U} \text { or } \mathrm{M} / \\
\mathrm{P}, \\
\text { molar ratio }\end{array}$ & $\begin{array}{c}37 \% \\
\mathrm{CH}_{2} \mathrm{O} \\
\mathrm{g}\end{array}$ & $\begin{array}{c}\mathrm{CH}_{2} \mathrm{O} / \\
\mathbf{P}+\mathrm{U} \text { or } \\
\mathbf{P}+\mathbf{M}, \\
\text { molar ratio }\end{array}$ & $\mathrm{pH}$ & $\underset{{ }^{\circ} \mathrm{C}}{\mathrm{Temp}}$ & $\begin{array}{c}\text { Reaction } \\
\text { time } \\
\text { min }\end{array}$ & $\begin{array}{l}\text { Resin } \\
\text { yield, } \\
\quad \mathrm{g}\end{array}$ & $\begin{array}{l}\mathrm{P}, \\
\%\end{array}$ & $\begin{array}{l}\mathrm{N} \\
\%\end{array}$ \\
\hline $24^{\prime \prime}$ & 0.5 & $\mathrm{U} 1.20$ & 10 & 5.42 & 3.0 & 5.2 & 50 & 65 & 0.30 & 6.2 & 25.2 \\
\hline $24^{\prime}$ & 0.25 & U0.60 & 10 & 2.71 & 3.0 & 5.6 & 50 & 82 & 1.06 & 6.3 & 26.0 \\
\hline 24 & 0.25 & U0.60 & 10 & 2.71 & 3.0 & 5.4 & 50 & (ca. $9 \mathrm{~h}$ ) & 1.50 & 5.9 & 24.8 \\
\hline $30^{\prime \prime}$ & 0.5 & M1.26 & 5 & 6.32 & 6.5 & 5.1 & 50 & 18 & 0.44 & 5.7 & 31.3 \\
\hline $30^{\prime}$ & 0.25 & M0.63 & 5 & 3.16 & 6.5 & 5.4 & 50 & 25 & 1.30 & 5.3 & 32.1 \\
\hline 30 & 0.25 & M0.63 & 5 & 3.16 & 6.5 & 5.3 & 50 & (ca. $8.5 \mathrm{~h}$ ) & 1.65 & 5.7 & 31.9 \\
\hline
\end{tabular}

a No. $24^{\prime \prime}$ and $30^{\prime \prime}$, product obtained before gelation; No. $24^{\prime}$ and $30^{\prime}$, product after gelation; No. 24 and 30 , perfected resin. 


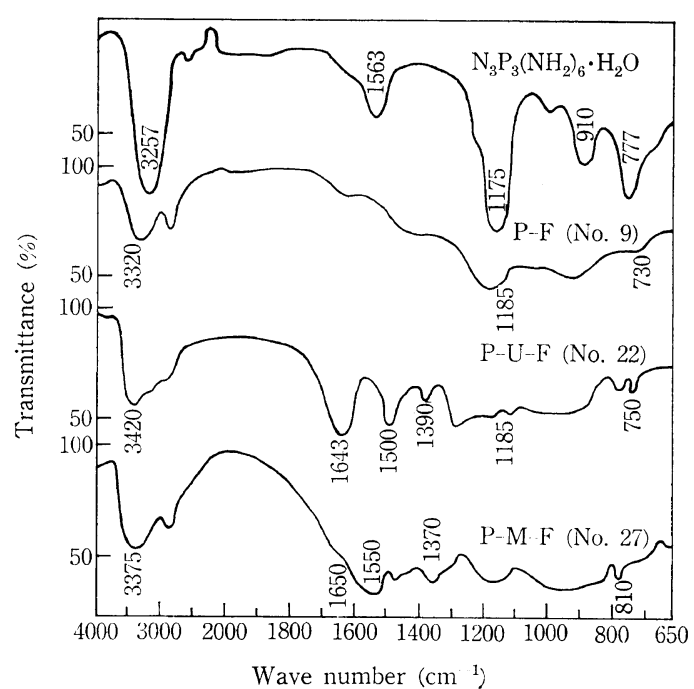

Figure 2. Infrared spectra of trimeric phosphorus diamide nitride and resin: $\mathrm{P}-\mathrm{F}$, phosphorus amideformalin resin: $\mathrm{P}-\mathrm{U}-\mathrm{F}$, phosphorus amide-ureaformalin resin; $\mathbf{P}-\mathbf{M}-\mathbf{F}$, phosphorus amide-melamine-formalin resin.

$810 \mathrm{~cm}^{-1}$. From these IR spectra results, the constituted radical of resin and its bond were determined.

\section{Thermal Decomposition of Resin}

Trimeric and tetrameric phosphorus diamide nitrides have considerable thermal stability as shown in our previous report. ${ }^{8}$ Therefore, the resins, which used $\mathrm{N}_{n} \mathrm{P}_{n}\left(\mathrm{NH}_{2}\right)_{2 n}$ as a raw material, may be expected to have a fire-resistant quality. The DTA and TGA curves for several resins are shown in Figure 3.

The resin of the $\mathrm{CO}\left(\mathrm{NH}_{2}\right)_{2}-\mathrm{CH}_{2} \mathrm{O}$ system decomposed quickly within 250 to $260^{\circ} \mathrm{C}$, and the resulting carbonized product continued to burn as a smoldering fire, and incinerated completely at $650^{\circ} \mathrm{C}$. The resin of the $\mathrm{N}_{3} \mathrm{P}_{3}\left(\mathrm{NH}_{2}\right)_{6}-$ $\mathrm{CO}\left(\mathrm{NH}_{2}\right)_{2}-\mathrm{CH}_{2} \mathrm{O}$ system, containing $8.9 \% \mathrm{P}$, began to decompose at $230-240^{\circ} \mathrm{C}$, but the carbonized product resisted combustion, and then remained at a weight of about $20 \%$ at $700^{\circ} \mathrm{C}$. The resin of the $\mathrm{C}_{3} \mathrm{H}_{6} \mathrm{~N}_{6}-\mathrm{CH}_{2} \mathrm{O}$ system, which may contain some methyl group, started thermal decomposition at about $210^{\circ} \mathrm{C}$; the carbonized product flamed up at $400^{\circ} \mathrm{C}$, and they incinerated completely at about $700^{\circ} \mathrm{C}$. In the resin of the $\mathrm{N}_{3} \mathrm{P}_{3}\left(\mathrm{NH}_{2}\right)_{6}-\mathrm{C}_{3} \mathrm{H}_{6} \mathrm{~N}_{6}-\mathrm{CH}_{2} \mathrm{O}$ system, containing $9.2 \% \mathrm{P}$, the starting temperature of

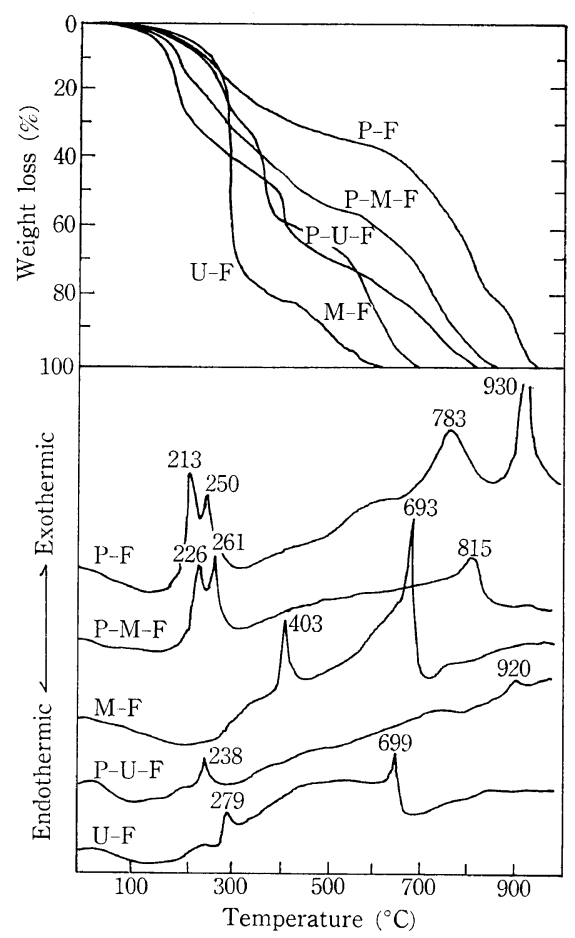

Figure 3. DTA and TGA curves for various resins: $\mathrm{M}-\mathrm{F}$, melamine-formalin resin; $\mathrm{U}-\mathrm{F}$, urea-formalin resin. $\mathrm{P}-\mathrm{F}, \mathrm{P}-\mathrm{U}-\mathrm{F}$, and $\mathrm{P}-\mathrm{M}-\mathrm{F}$ are indicated in Figure 2.

thermal decomposition shifted more to the lower temperature side than that of those resins containing no phosphorus. On the DTA curve, a branched exothermic peak appeared at 226 and $261^{\circ} \mathrm{C}$, these indicating a flash ignition temperature of inflammable gas and a self-ignition temperature of the carbonized product. In this case, the weight of the residue was $35 \%$ at $700^{\circ} \mathrm{C}$; the residue remarkably resisted combustion, and incinerated at about $800^{\circ} \mathrm{C}$. In the resin of the $\mathrm{N}_{3} \mathrm{P}_{3}\left(\mathrm{NH}_{2}\right)_{6}-\mathrm{CH}_{2} \mathrm{O}$ system, containing $24.4 \% \mathrm{P}$, the temperature of the thermal decomposition shifted to the lower temperature side such as 213 and $250^{\circ} \mathrm{C}$. However, its carbonized product remained at 75,58 , and 30 weight $\%$ at 350,700 , and $800^{\circ} \mathrm{C}$, respectively. It is suggested that two exothermic peaks appearing at high temperatures $\left(783,930^{\circ} \mathrm{C}\right)$ indicate the combustion of the carbonized product and finally the formed phospham $\left(\mathrm{PN}_{2} \mathrm{H}\right)_{n}$.

Swelling and Weight Loss of Resin by Heating The states of the resins heated at $600^{\circ} \mathrm{C}$ for 


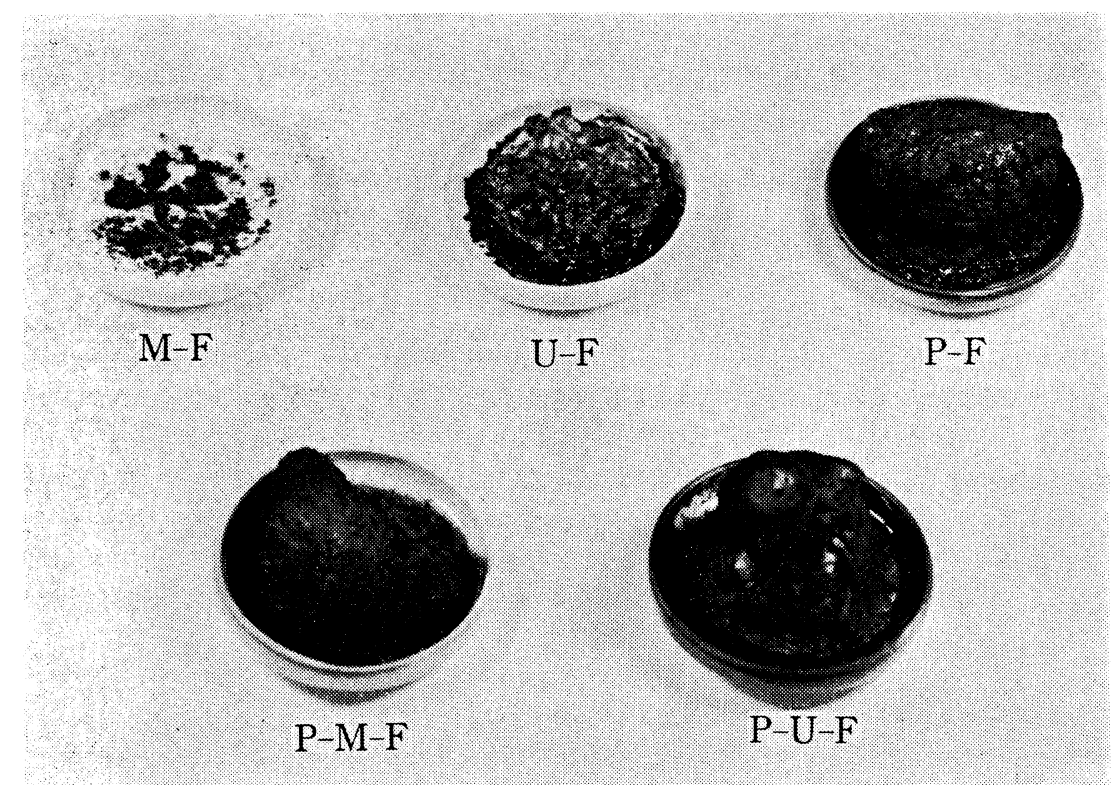

Figure 4. The states of resins heated at $600^{\circ} \mathrm{C}$ for $3 \mathrm{~min}$. Symbols are indicated in Figures 2 and 3.

3 min are shown in Figure 4, and the weight losses of resins are shown in Figure 5. As seen in the photograph, the resin of the $\mathrm{C}_{3} \mathrm{H}_{6} \mathrm{~N}_{6}-\mathrm{CH}_{2} \mathrm{O}$ system scarcely swelled up, and its carbonized product remained a powder. The resin of the $\mathrm{CO}\left(\mathrm{NH}_{2}\right)_{2}-\mathrm{CH}_{2} \mathrm{O}$ system grew bulky to about 5 times its volume. The resin of the $\mathrm{N}_{3} \mathrm{P}_{3}\left(\mathrm{NH}_{2}\right)_{6}$ $\mathrm{CH}_{2} \mathrm{O}$ system, containing $25.5 \% \mathrm{P}$, grew bulky to about 40 times its volume, and a fine carbonized product was formed. The resins of the $\mathrm{N}_{3} \mathrm{P}_{3}\left(\mathrm{NH}_{2}\right)_{6}-\mathrm{C}_{3} \mathrm{H}_{6} \mathrm{~N}_{6}-\mathrm{CH}_{2} \mathrm{O}$ and $\mathrm{N}_{3} \mathrm{P}_{3}\left(\mathrm{NH}_{2}\right)_{6}-$

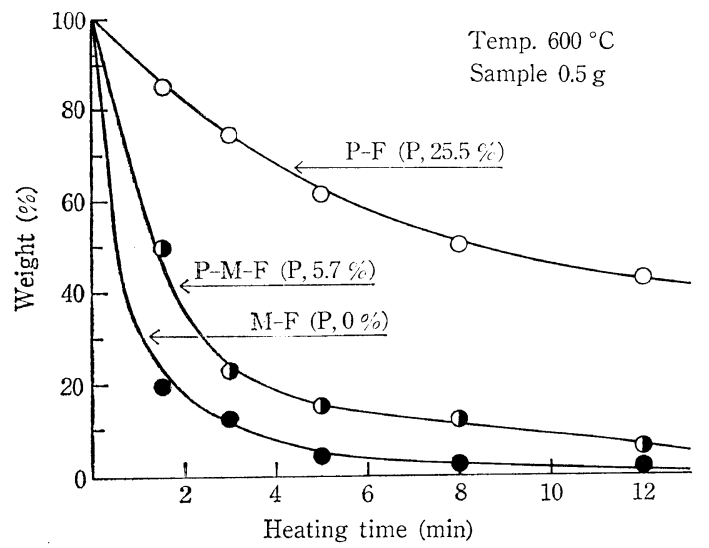

Figure 5. Thermal decomposition of resins. Symbols are indicated in Figures 2 and 3.
$\mathrm{CO}\left(\mathrm{NH}_{2}\right)_{2}-\mathrm{CH}_{2} \mathrm{O}$ systems, containing 5.7 and $5.9 \% \mathrm{P}$, swelled more than the melamine and urea resins. However, no carbonized products formed as fine structures, and then the volume and weight were decreased by further heating. Generally, fireproof abilities are effective with the fine structure of carbonized product. Also, it is known that there is a linear relation between the swelling volume and fire retardation time. $^{11}$

Weight loss of the resin of the $\mathrm{N}_{3} \mathrm{P}_{3}\left(\mathrm{NH}_{2}\right)_{6}-$ $\mathrm{CH}_{2} \mathrm{O}$ system was less than that of the melamine resin as seen in Figure 5. Therefore, in the resin used $\mathrm{N}_{n} \mathbf{P}_{n}\left(\mathrm{NH}_{2}\right)_{2 n}$ as raw material, an effect of fire retardation may be expected.

\section{REFERENCES}

1. C. A. Redfarn and H. Coates, British Patent 788785 (1958).

2. E. R. Nielsen and W. L. Stepp, U.S. Patent 3348926 (1967).

3. T. Z. Wakefield, E. S. Allen, F. J. McCullough, C. R. Sheridan, and J. J. Kohlen, J. Agr. Food Chem., 19, 99 (1971).

4. W. Wanek, L. Ondracek, and J. Hampl, $Z$. Pflanzenernaehr. Bodenkd. 128 (3), 169 (1971); Agrokhimiya, 11 (6), 177 (1971).

5. E. Kobayashi, Nippon Kagaku Kaishi, 38 (1972); 
Tokyo Kogyo Shikensho Hokoku, 68, 19 (1973).

6. E. Kobayashi, Chem. Lett., 479 (1976); Bull. Chem. Soc. Jpn., 46, 3524 (1976).

7. E. Kobayashi, Nippon Kagaku Kaishi, 1437 (1973); Tokyo Kogyo Shikensho Hokoku, 69, 470 (1974).

8. E. Kobayashi and T. Kanayama, Bull. Chem.
Soc. Jpn., 47, 307 (1977).

9. L. F. Audrieth and D. S. Sowerby, Chem. Ind., 748 (1957).

10. K. Katsuura, Kobunshikako Betusatsu, 19, 35 (1970).

11. N. Shikazono, H. Kamata, and T. Kanayama, Tokyo Kogyo Shikensho Hokoku, 52, 228 (1957). 